\title{
Immersive hand hygiene trainer for physicians - a story-based serious game
}

\author{
HS Sax ${ }^{1 *}, Y$ Longtin $^{2}$ \\ From International Conference on Prevention \& Infection Control (ICPIC 2011) \\ Geneva, Switzerland. 29 June - 2 July 2011
}

\section{Introduction / objectives}

Hand hygiene is a simple yet often omitted gesture to prevent pathogen transmission and healthcare-associated infections. Training healthcare workers in hand hygiene is a key element in any multifaceted promotion strategy. Physicians are notoriously known for their underperformance in this field. We sought to design a natural immersive environment to improve physicians' hand hygiene performance.

\section{Methods}

We inserted filmed sequences based on a plot of two physicians interacting with different patients during ward rounds into an interactive computer interface allowing the physician 'gamer' to decide where to use hand hygiene and disposable gloves. Hand hygiene being a very repetitive and often subconsciously executed task, virtual immersion might increase learning and improve long-term retention. Thus, we used both an emotionally engaging but also distracting plot to create role identity and simulate mental load typical for medical activity on the ward. Design features were refined through individual think-aloud protocols and target group testing. Immediate feedback messages and a result tracking mechanism were added.

\section{Results}

The design specifications could all be met. The resulting application proofed equally suitable for the training of hand hygiene observers. Computing the user's results allows for benchmarking.
'Infection control program, University of Geneva Hospitals and Medical Faculty, Geneva, Switzerland

Full list of author information is available at the end of the article

\section{Conclusion}

A serious game was successfully launched immersing the 'gamer' into the real-life challenge of hand hygiene. Post-launch evaluation and clinical effectiveness have to be performed in a next step.

\section{Disclosure of interest}

None declared.

\section{Author details}

${ }^{1}$ Infection control program, University of Geneva Hospitals and Medical Faculty, Geneva, Switzerland. ${ }^{2}$ Infectious diseases, Centre Hospitalier Universitaire de Québec, Québec, Canada.

Published: 29 June 2011

\section{doi:10.1186/1753-6561-5-S6-031}

Cite this article as: Sax and Longtin: Immersive hand hygiene trainer for physicians - a story-based serious game. BMC Proceedings 2011 5(Suppl 6):O31.
Submit your next manuscript to BioMed Central and take full advantage of:

- Convenient online submission

- Thorough peer review

- No space constraints or color figure charges

- Immediate publication on acceptance

- Inclusion in PubMed, CAS, Scopus and Google Scholar

- Research which is freely available for redistribution
C Biomed Central

\section{Biomed Central}

